\title{
Effect of the Number of Years of Soil Exploitation by Saffron Cultivation in Morocco on the Diversity of Endomycorrhizal Fungi
}

\author{
I. EL AYMANI, S. EL GABARDI, M. ARTIB, M. CHLIYEH, K. SELMAOUI, \\ A. OUAZZANI TOUHAMI, R. BENKIRANE and A. DOUIRA* \\ Laboratory of Botany, Biotechnology and Plant Protection, Department of Biology, \\ Faculty of Sciences, Ibn Tofail University, BP. 133, Kenitra, Morocco
}

(Received: 30 August 2018; accepted: 8 October 2018)

\begin{abstract}
The diversity of endomycorrhizal fungi in the rhizosphere of Crocus sativus has been studied at five sites in the Taliouine region (Tinfat), located in Taroudant Province (Morocco), according to the number of years of soil exploitation by Saffron cultivation. In all sites, the roots of Crocus sativus carry structures of endomycorrhizal fungi. Root mycorrhizal frequencies are very high in site 1 (93.33\%); site 2 (96.67\%); site $4(90 \%)$ and in site $6(93.33 \%)$. In these sites, the spore density is, respectively, 39, 58, 138, 99 spores / $100 \mathrm{~g}$ of soil. The frequency of root mycorrhization is lower at the site $(76.66 \%)$ which also exhibited a spore density of 27 spores / $100 \mathrm{~g}$ of soil.

The identification of isolated spores made it possible to note the presence of 36 species belonging to 6 genera: Glomus (15 species), Acaulospora (10 species), Scutellospora (6 species), Gigaspora (2 species), Pacispora (2 species), Entrophospora (1 species). Species such as Glomus clarum, G. etunicatum, G. aggregatum, G. intraradices, Acaulospora laevis, Scutellospora coralloidea, were present in all studied sites.

The greatest richness of MA fungi was registers in the site at four successive years of exploitation by Saffron (24 species), with a Shannon diversity index $\mathrm{H}=2.82$ which is the highest among all studied sites, followed by the site at six years of occupation by Saffron ( 21 species), with $\mathrm{H}^{\text {' }}=2.61$, while the lowest number of species was recorded in sites of two, three and ten years of exploitation of sol by Saffron, with $\mathrm{H}$ '= 1.77, respectively; 2.12 and 2.44 .

This decrease in endomycorrhizal species richness confirms that Crocus sativus residues are probably the cause. In fact, the prolonged occupation of plots with safrana has an allelopathic effect on mycoflora and on the yield of Saffron.
\end{abstract}

Keywords: Saffron, allelopathy, diversity, endomycorrhizal, Morocco.

In Morocco, saffron (Crocus sativus L.) has been cultivated for years in the Taliouine area (Taroudant Province) over an area of 565 ha, and more recently in the Taznakht area (Ouarzazate province) over an area of of 105 ha (Aboudrare et al., 2014). Although Morocco is a small producer (3 tons), it is ranked fourth producer of Safran after Iran, India and Greece, with only $1.5 \%$ of total world production (Dubois, 2010). Moroccan saffron is highly reputed nationally and internationally (Lage and Cantrell, 2009). It constitutes one of the main supports of the economy of the Taliouine-Taznakht region, 
characterized by difficult pedoclimatic conditions (Garcin and Carral, 2007), high rates of poverty and income inequality and a high level of rural-to-urban migration (Anonyme 1, 2004; Bouchelkha, 2009).

Among the objectives that have been highlighted by the strategy of the Green Morocco Plan in the Safran sector, 1. the increase in the area reserved for growing Saffron from 610 ha to 1,350 ha by 2020,2. improvement of Safran's production to reach 9 tons by 2020,3 . increase of quantities exported to 6 tons per year and 4. strengthening of research and technology transfer programs (Anonyme 2, 2015).

The development of saffron's culture depends on the development of new production techniques adapted to the pedoclimatic conditions of the regions favorable to this crop. Several studies have shown that soil fertility and productivity are highly related to soil biological activity (Onguene, 2000). The development of plants depends on the interactions they have with the environment, particularly with soil microorganisms. This is the case of mycorrhizae which are symbiotic of plant roots (Smith and Read, 1997). The mutualistic association observed between vesicular and arbuscular mycorrhizas (MVA) and host plants are important in various natural and agricultural ecosystems (Sylvia and Williams, 1992). About $80 \%$ of the higher plants are associated with mycorrhizal arbuscular fungi (AMF) that provide the ecological stability of the environment (Harley and Smith, 1983; Strullu, 1991). Their importance in natural and semi-natural ecosystems is to improve the absorption of water and nutrients such as phosphorus, nitrogen and micronutrients, thereby improving plant growth and resistance to biotic and abiotic stresses (Goussous and Mohammad, 2009; Lone et al., 2015a, b).

The yield depends on the number of years of occupation of the plot by Saffron cultivation. In general, the yield decreases and over time the plot is no longer used for this crop. This decrease in yield is probably due to changes in the physicochemical and biochemical properties of the soil and changes in soil microorganism population structure that may occur after a period of Saffron cultivation on the same soil (Qarai and Beigi, 1995). Khozaei et al. (2015) observed that the continuous cultivation of Saffron on the same soil causes an undesirable change in the chemical and physical properties of the soil, the effect of these changes is very significant after six years of cultivation on the same soil, Jalali (1962) noted that after a period of cultivation, Saffron cannot be grown in the same soil. Azizi Zohan and Sepaskhah (2002) reported allelopathic effects and the accumulation of special salts in the root zone of saffron plants after a long period of cultivation on the same soil. The effect of these changes on the population structures of rhizosphere microorganisms in Saffron plants, the case of endomycorrhizal fungi, is not well known. This phenomenon is called allelopathy which is a problem that requires further research (Khozaei et al., 2015). Sharif and Moawad (2006) noted that the diversity of AM fungi species in agricultural systems is highly influenced by different types of inputs. The effect, for example, of the tissue extract of one plant species on the growth or reproduction of another species has been observed in many cases (Jadhav et al., 1997; Hoseini and Rizvi, 2003; Kobayashi, 2004).

In this work, the effect of the operating life of Saffron plants was studied on the diversity of endomycorrhizal fungi of Safran plants in the Taliouine (Tinfat) region of Morocco. 


\section{Materials and Methods}

\section{Prospecting and sampling}

Soil samples were collected from six field sites in the Taliouine region (Tinfat), Province of Taroudant (Morocco). Each site is characterized by the number of years of land use by Saffron. The soil of the site 1 never carried saffron and the soils of sites 2, 3, 4, 5 and 6 were exploited, respectively, during 2, 3, 4, 5 and 6 years.

Soil samples were taken from the rhizosphere of Crocus sativus plants at a depth of 0-20 cm. Very fine roots, likely to be mycorrhized and easily observable under the microscope, were also taken with the soil.

\section{Root coloring}

The roots are cleaned of soil particles by thorough rinsing with tap water in a sieve. Then only the smallest fine roots are selected.

According to the lightening technique and Philips and Hayman (1970) coloring, the roots are cut into fragments of approximately 1 to $2 \mathrm{~cm}$ and placed in vials containing 10 $\mathrm{ml}$ of a potassium hydroxide solution $(\mathrm{KOH}) 10 \%$. These flasks are then placed in a water bath at $90{ }^{\circ} \mathrm{C}$ for $15 \mathrm{~min}$. The root fragments are then bleached by adding a few drops of $\mathrm{H}_{2} \mathrm{O}_{2}$ to the $\mathrm{KOH}$ solution. After $15 \mathrm{~min}$, the fragments are rinsed with distilled water and then stained with a solution of Cresyl blue (0.05\%) for $15 \mathrm{~min}$.

\section{Evaluation of mycorhization rate}

Evaluation of the mycorrhizal parameters was performed by observing thirty root fragments of about $1 \mathrm{~cm}$, randomly chosen to quantify the mycorrhizae (Kormanik and McGraw, 1982; Amir and Renard, 2003). These fragments are mounted parallel in groups of 10 to 15 in a drop of glycerine water between blade and coverslip (Kormanik and McGraw, 1982). Each fragment was thoroughly checked over its entire length, at magnifications $\times 100$ and $\times 400$.

The frequency and levels of arbuscules and vesicles of AMF within the root bark are measured by assigning a mycorrhizal index ranging from 0 to 5 (Derkowska et al., 2008):

0 : absence; 1 : traces; 2 : less than $10 \%$; 3 : from 11 to $50 \%$; 4 : from 51 to $90 \% ; 5$ : more than $91 \%$

Frequency of mycorrhization $(\mathrm{F} \%)$ :

$$
\mathrm{F} \%=100 \times\left(\mathrm{N}-\mathrm{n}_{0}\right) / \mathrm{N}
$$

- With, $\mathrm{N}$ : number of fragments observed and $\mathrm{n}_{0}$ : number of non-mycorrhizal fragments.

Intensity of mycorrhization (M\%):

$$
\mathrm{M} \%=(95 \mathrm{n} 5+70 \mathrm{n} 4+30 \mathrm{n} 3+5 \mathrm{n} 2+\mathrm{n} 1) / \mathrm{N}
$$

- With, $\mathrm{n}=$ number of affected fragments of the index $0,1,2,3,4$ or 5

Teneur en arbuscules (A\%):

$$
\mathrm{A} \%=(100 \mathrm{~mA} 3+50 \mathrm{~mA} 2+10 \mathrm{~mA} 1) / 100
$$


Where $\mathrm{mA} 3, \mathrm{~mA} 2, \mathrm{~mA} 1$ are assigned, respectively, the notes $\mathrm{A} 3, \mathrm{~A} 2, \mathrm{~A} 1$, with, $m A 3=(95 n 5$ A3 + $70 n 4$ A3 + $30 n 3$ A3 + $5 n 2$ A3 + n1 A3 $) /$ N. Similar is true for A1, A2.

In this formula, n5 A3 represents the number of fragments noted with A3; n4 A3 the number of fragments rated 4 with $\mathrm{A} 3$;

A0: no arbuscules; A1: few arbuscules 10\%; A2: moderately abundant arbuscules 50\%; A3: very abundant arbuscules: $100 \%$.

\section{Extraction of spores}

The spores were extracted by the wet sieving method described by Gerdemann and Nicolson (Gerdemann and Nicholson, 1963; Nicolson and Johnston, 1979). In a 1-liter beaker, $100 \mathrm{~g}$ of each soil sample was immersed in $0.5 \mathrm{~L}$ of tap water and shaken with a spatula for 1 minute. After 10 to 30 seconds of settling, the supernatant is passed through four superposed sieves with decreasing meshes $(500,200,80$ and $50 \mu \mathrm{m})$. This operation was repeated twice. The contents retained by the 200,80 and 50 micron sieves were divided into two tubes and centrifuged for $4 \mathrm{~min}$ at $9000 \mathrm{rpm}$. The supernatant is discarded and a viscosity gradient is created by adding $20 \mathrm{~mL}$ of a $40 \%$ sucrose solution into each centrifuge tube (Walker and Mize, 1982). The mixture is rapidly stirred and the tube returned to the centrifuge for $1 \mathrm{~min}$ at $9000 \mathrm{rpm}$. Unlike the first centrifugation operation, the supernatant is poured onto the $50 \mu \mathrm{m}$ mesh sieve; the resulting substrate is rinsed with distilled water to eliminate sucrose, and then disinfected with an antibiotic solution (Streptomycin). The estimation of the number of spores in the soil was made by counting the spores contained in one $\mathrm{mL}$ of supernatant.

The characteristic structures (color, shape, size and number of separation membranes, etc.) of the spores are demonstrated by mounting between the slide and the plate of $0.1 \mathrm{~mL}$ of supernatant.

A preliminary identification of the spore genus was made based on the criteria proposed by Ferrer and Herrera (1981); Berch and Koske (1986); Schenck and Smith (1982); Hall (1987); Schenck and Perez (1987); Morton and Benny (1990); Walker and Mize (1982); Dalpé (1995); Mukerji and Kapoor (1986), and information available in different databases (Anonyme 3, 2016).

\section{Specific richness and frequency of appearance of spores}

The species richness represents the total number of species observed per collection site and the frequency of appearance of the species corresponds to the percentage of sites where each species is detected.

\section{The Margalef index:}

The Margalef index or Margalef biodiversity index is a measure used to estimate the biodiversity of a community based on the numerical distribution of individuals of different species according to the number of individuals in the sample (Margalef, 1958).

Where:

$$
\mathrm{I}_{\mathrm{M}}=(\mathrm{S}-1) / \mathrm{Ln} \mathrm{N}
$$

$\mathrm{S}=$ number of species present; 
$\mathrm{N}=$ total number of found individuals (belonging to all species);

$\mathrm{Ln}=$ natural logarithm of a number.

\section{Shannon-Wiener index}

The Shannon index is used to express diversity by taking into account the number of species and the abundance of individuals within each species. Thus, a community dominated by a species will have a lower coefficient than a community where all species co-dominate.

The index value ranges from 0 (one species, or one that largely dominates all others) to Ln S (when all species have the same abundance) (Shannon and Weaver, 1949).

$$
\mathrm{H}^{\prime}=\sum_{\mathrm{i}=1}^{\mathrm{s}}\left[\left(\frac{\mathrm{ni}}{\mathrm{N}}\right) \ln \left(\frac{\mathrm{ni}}{\mathrm{N}}\right)\right]
$$

Where:

$\mathrm{S}=$ total number of species;

$\mathrm{ni}=$ number of individual species in the sample;

$\mathrm{N}=$ total number of individuals of all species in the sample.

\section{Results}

In all the studied sites, the roots of Saffron were mycorrhizal. Different characteristic structures of arbuscular endomycorrhizae have been observed: arbuscules, intracellular and extracellular hyphae, spores and endophytes (Fig. 1).

Mean root mycorrhizal frequencies vary from one site to another (Table 1), the maximum value was $96.67 \%$ at the level of site 3, occupied for three years by Saffron, and the minimum value was $76.66 \%$ at the site operated for four years. The highest mean mycorrhizal intensity $(45.9 \%)$ was noted in the roots of plants growing in a site operated for four years by Saffron and the lowest value $(21.2 \%)$ in the site operated for ten years. The contents of the root on arbuscules were important at sites that carried the Saffron for four and six years, respectively, $44.9-45.3 \%$.

The average number of spores noted in the rhizosphere of Crocus sativus plants is also a function of the studied sites. The lowest number is observed ( 27 spores / $100 \mathrm{~g}$ of soil) in the site exploited for 10 years (site 10) and the highest (138 spores / $100 \mathrm{~g}$ of soil) at the site which carried the saffron during 4 years.

\section{Table 1}

Mean frequencies and intensities of mycorhization and arbuscular content of the roots of saffron plants in the different studied sites

\begin{tabular}{llllll}
\hline & Site 2 & Site 3 & Site 4 & Site 6 & Site 10 \\
\hline Frequency \% & 99.33 & 96.67 & 90 & 93.33 & 76.66 \\
Mycorrhizal intensity \% & 31.96 & 30.33 & 45.9 & 32.3 & 21.2 \\
Arbuscule \% & 25.6 & 28.2 & 44.9 & 45.3 & 21.2 \\
\hline
\end{tabular}




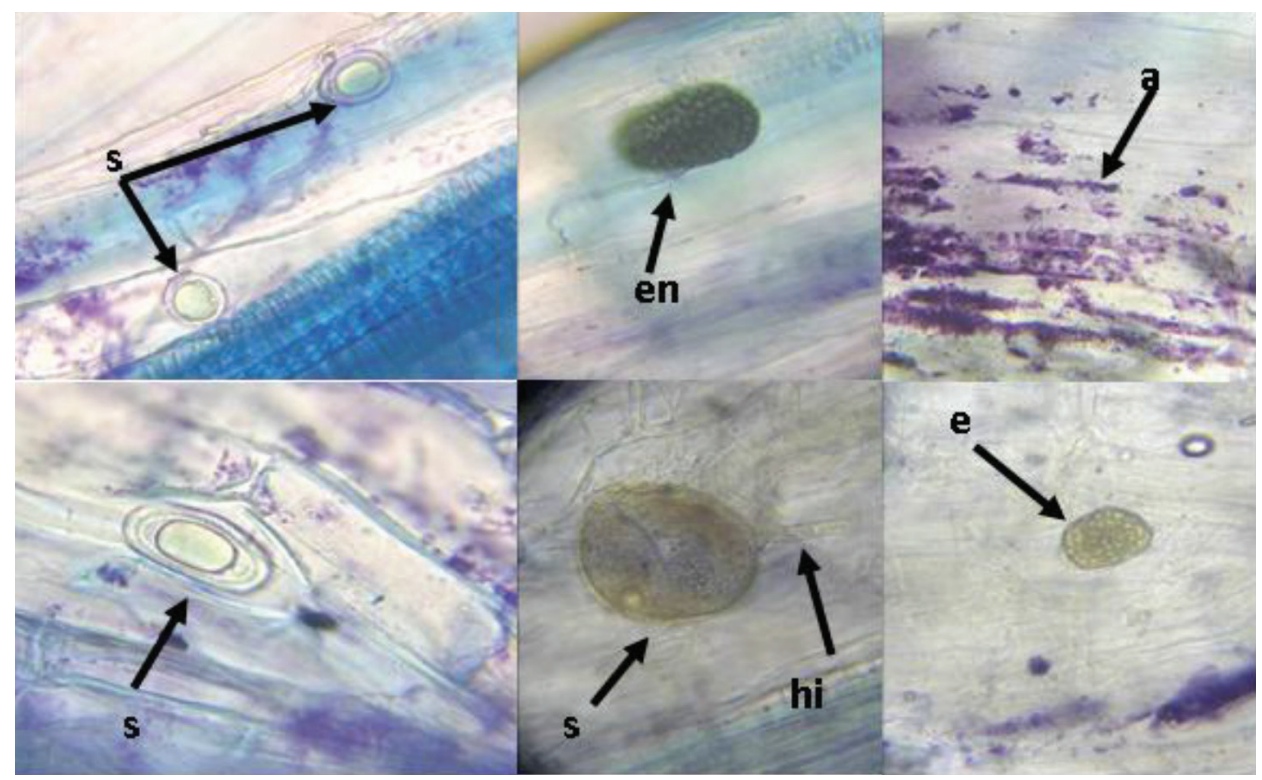

Fig. 1. Crocus sativus roots with arbuscular mycorrhizal structures: arbuscles (a); Intraductal hyphee (hi), spores (s); and endophytes (en). (G. × 400)

From these results, it appears that, in general, the optimum for all the mycorhization parameters is observed at the sites exploited during 3 (frequency of mycorrhization), 4 (intensity of mycorrhization and number of spores) or 6 (number of arbuscules) years.

MA fungi isolated from the saffron rhizosphere (Crocus sativus) of the studied sites were identified according to the morphological characteristics of the spores (Table 2 and Fig. 2).

Species richness (Table 4) varies from site to site. The highest number (24 species) is observed at the site occupied for 4 years by Saffron. The lowest number was recorded in sites operated during 2, 3 and 10 years of soil use by Saffron ( 9 and 10 species).

All the encountred species in the different studied sites belong to six genera: Glomus (15 species), Acaulospora (10 species), Scutellospora (6 species), Gigaspora (2 species), Pacispora (2 species), and Entrophospora (1 species).

In the site operated for two years by Saffron (Table 4), Acaulospora sp. 1 and Glomus macrocarpum are the most abundant species, with, respectively, a spore count of 16 and 6 spores / $100 \mathrm{~g}$ of soil. At the level of the exploited site during three years, the species which abound are Acaulospora sp. 1 (11 spore / $100 \mathrm{~g}$ of soil), Glomus sp. 1 and Gigaspora decipiens, with a number of spores count of 11 and 8 spore / $100 \mathrm{~g}$ soil. In the site occupied for four years by the Saffron, the most prominent species are Entrophospora infrequens (19 spores / $100 \mathrm{~g}$ soil), Glomus aggregatum, Glomus etunicatum (15 spores / 100 g soil), Acaulospora laevis and Acaulospora sp. 1, represented, respectively, by 13 and 10 spores / $100 \mathrm{~g}$ of soil). In the site cultivated for six years by Saffron, the most common species are Glomus mosseae, G. aggregatum and Acaulospora denticulata, with, respectively, 13, 9 and 8 spores / $100 \mathrm{~g}$ soil. In site 10, exploited during 10 years, the species encountered, with a low number of spores (4 spores / $100 \mathrm{~g}$ of the soil) are Acaulospora acrobiculata, Glomus etunicatum, G. intraradices and Scutellospora coralloidea. 
In the five studied sites (Table 3), Glomus macrocarpum, G. etunicatum, G. clarum and Acaulospora sp. 1 are distributed in 4 different sites with a distribution percentage of 80\%. Acaulospora denticulata, A. laevis, Glomus aggregatum, G. intraradices, Glomus. sp. 1, Gigaspora decipiens, Scutellospora castanea and are distributed in three different sites, with a distribution percentage of $60 \%$. Acaculospora mellea, A. morrowiae, Entrophospora infrequens, Glomus mosseae, G. heterosporum, Gigaspora sp. 1, Pacis-

\section{Table 2}

Identification of mycorrhizal fungi isolated from the rhizosphere of Crocus sativus in the different study sites

\begin{tabular}{|c|c|c|c|c|c|c|c|}
\hline $\mathrm{N}_{0}$ & Name & Form & Color & $\begin{array}{l}\text { Size of the } \\
\text { spore } \mu \mathrm{m}\end{array}$ & $\begin{array}{c}\text { Wall size } \\
\mu \mathrm{m}\end{array}$ & $\begin{array}{c}\text { Length } \\
\text { of hyphae } \\
\mu \mathrm{m}\end{array}$ & $\begin{array}{c}\text { Surface } \\
\text { of the } \\
\text { spore }\end{array}$ \\
\hline 1 & Scutellospora sp. 1 & Globular & yellow & 119.88 & 6.66 & - & granular \\
\hline 2 & Glomus macrocarpum & Globular & light brown & 116.55 & 9.32 & - & smooth \\
\hline 3 & Glomus aggregatum & Globular & light brown & 113.22 & 10 & - & smooth \\
\hline 4 & Glomus heterosporum & Globular & dark brown & 96.57 & 8.65 & - & smooth \\
\hline 5 & Glomus sp. 2 & Irregular & dark yellow & 125.4 & 2.33 & - & smooth \\
\hline 6 & Pacisporaboliviana & Oval & dark yellow & 176.49 & 11.65 & - & smooth \\
\hline 7 & Acaulospora denticulata & Irregular & yellow & 127.87 & 3.33 & - & smooth \\
\hline 8 & Glomus etunicatum & Globular & brown & 139.86 & 11.65 & - & smooth \\
\hline 9 & Acaulospora morrowiae & Globular & brown & 106.52 & 1.9 & 79.92 & granular \\
\hline 10 & Glomus intraradices & Irregular & brown & 73.26 & 16.65 & - & granular \\
\hline 11 & Glomus deserticola & Globular & pale yellow & 103.23 & 4.9 & - & granular \\
\hline 12 & Acaulospora sp. 1 & Globular & pale yellow & 83.25 & 1.67 & 23.31 & granular \\
\hline 13 & Scutellospora fulgida & Irregular & dark yellow & 113.22 & 4.23 & - & granular \\
\hline 14 & Gigaspora decipiens & Irregular & dark brown & 99.9 & 4.29 & 136.53 & smooth \\
\hline 15 & Glomus microcarpum & Irregular & light brown & 129.87 & 9.99 & - & granular \\
\hline 16 & Scutellospora sp. 2 & Globular & yellow & 89.91 & 3.9 & - & granular \\
\hline 17 & Gigaspora sp. 1 & Oval & green & 93.24 & 2.9 & - & granular \\
\hline 18 & Acaulospora foveata & Jaune & oval & 49.95 & 5.32 & 33.3 & granular \\
\hline 19 & Acaulospora colossica & Globular & yellow & 96.57 & 8.32 & - & granular \\
\hline 20 & Acaulospora gedanensis & Globular & hyalin & 123.21 & 13.2 & - & smooth \\
\hline 21 & A. laevis & Oval & brown & 96.57 & 6.66 & - & granular \\
\hline 22 & Glomus margarita & Globular & yellow & 139.86 & 8.35 & - & granular \\
\hline 23 & Scutellospora castanea & Globular & yellow & 73.26 & 3.33 & - & granular \\
\hline 24 & Glomus sp. 1 & Globular & brown & 89.91 & 3.33 & - & smooth \\
\hline 25 & Glomus mosseae & Globular & hyalin & 89.91 & 9.99 & - & smooth \\
\hline 26 & Glomus clarum & Globular & brown & 106.56 & 13.32 & 116.55 & granular \\
\hline 27 & Entrophospora infrequens & Globular & dark brown & 63.27 & 3.33 & - & granular \\
\hline 28 & Scutellospora heterogama & Globular & brown & 113.22 & 8.9 & - & smooth \\
\hline 29 & Acaulospora mellea & Globular & yellow & 76.59 & 5 & 53.28 & smooth \\
\hline 30 & Acaulospora scrobiculata & Irregular & yellow & 103.23 & 7.9 & - & granular \\
\hline 31 & Acaulospora sp. 2 & Globular & brown & 119.88 & 10 & - & granular \\
\hline 32 & Glomus corymbiform & Irregular & hyalin & 136.53 & 3.33 & - & granular \\
\hline 33 & Glomus eburneum & Irregular & yellow & 56.58 & 3.66 & - & granular \\
\hline 34 & Glomus fecundisporum & Oval & dark yellow & 76.59 & 3.33 & - & granular \\
\hline 35 & Pacispora sp. & Globular & yellow & 63.27 & 4.9 & - & smooth \\
\hline 36 & Scutellospora coralloidea & Globular & dark brown & 149.85 & 6.66 & - & smooth \\
\hline
\end{tabular}




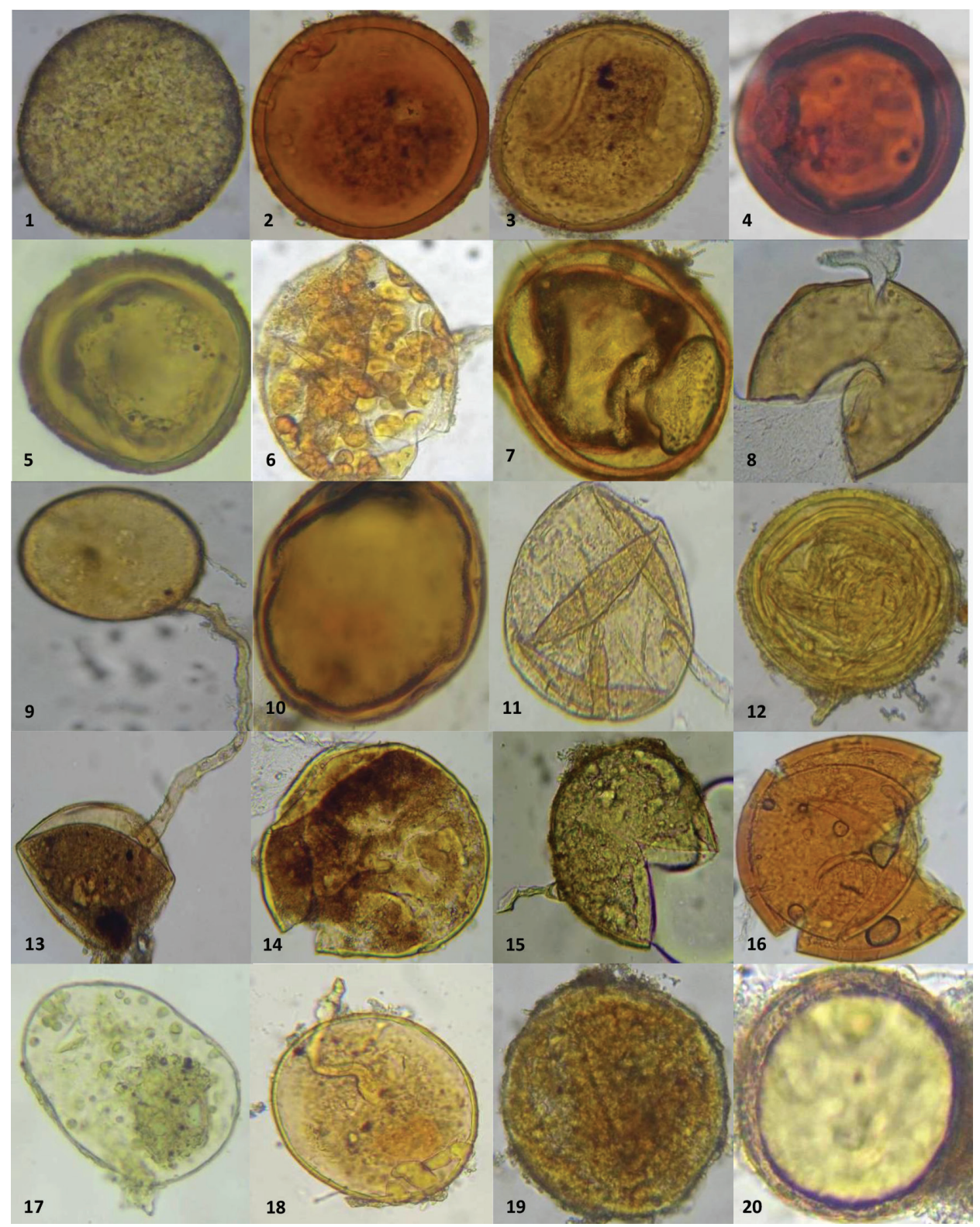

Fig. 2. Endomycorrhizal fungi isolated from the rhizosphere of Crocus sativus

pora boliviana, Pacispora sp. and Scutellospora fulgida are found in two different sites, with a distribution percentage of $40 \%$. In contrast, Acaulospora colossica, Acaulospora gedanensis, Acaulospora foveata, Acaulospora scrobiculata, Acaulospora sp. 2, Glomus corymbiform, G. adeserticola, G. eburneum, G. fecundisporum, G. margarita, G. microcarpum, Glomus sp. 2, Scutellospora heterogama, Scutellospora sp. 1, Scutellosporas sp. 2 were observed in only one site, with a distribution percentage of $20 \%$. 


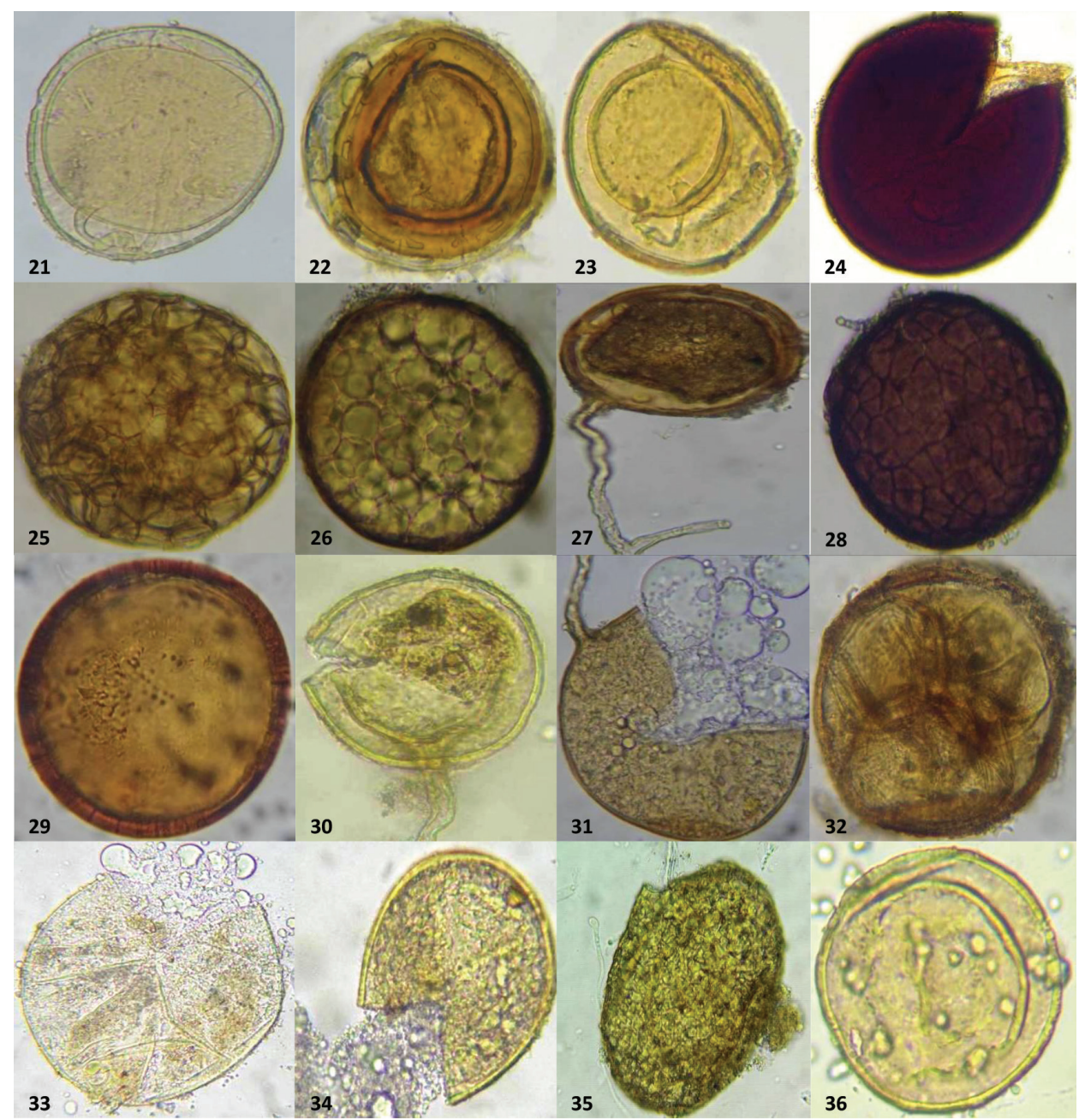

Fig. 2. (Cont.)

The distribution of the different genera of AM fungi in the studied sites is shown in Table 5. The Glomus and Acaulospora genera are present at six sites. The percentage of distribution of the genus Glomus varies from $8.33 \%$ to $30.56 \%$ and that of the Acaulospora genus, reaches $13.89 \%$ at the site which took six years of Saffron. The Scutellospora genus is present in four Saffron sites (site two, four, six and ten years), with distribution percentages ranging from $2.78 \%$ (two-year site) to $13.89 \%$ (six-year site). The Entrospora, Gigaspora and Pacispora genera are encountered in three different sites, with a distribution percentage not exceeding 5.56.

The diversity of AM fungi in the different studied sites varies from one site to another (Table 6). Shannon's diversity index is higher in the site operated for four years $\left(\mathrm{H}^{\prime}=2.82\right)$, followed by the six-year site $\left(\mathrm{H}^{\prime}=2.61\right)$. The site that has never been cultivated by Saffron recorded the lowest Shannon index (1.59). 
Table 3

Frequency and percentage distribution of AM fungal species present in the soil of the different studied sites

\begin{tabular}{|c|c|c|}
\hline Mycorrhizal species & Frequency of distribution & Percentage of distribution \\
\hline Acaulospora colossica & 1 & 20 \\
\hline Acaulospora gedanensis & 1 & 20 \\
\hline Acaulospora denticulata & 3 & 60 \\
\hline Acaulospora laevis & 3 & 60 \\
\hline Acaulospora foveata & 1 & 20 \\
\hline Acaulospora mellea & 2 & 40 \\
\hline Acaulospora morrowiae & 2 & 40 \\
\hline Acaulospora scrobiculata & 1 & 20 \\
\hline Acaulospora sp. 1 & 4 & 80 \\
\hline Acaulospora sp. 2 & 1 & 20 \\
\hline Entrophospora infrequens & 2 & 40 \\
\hline Glomus aggregatum & 3 & 60 \\
\hline Glomus clarum & 4 & 80 \\
\hline Glomus corymbiform & 1 & 20 \\
\hline Glomus deserticola & 1 & 20 \\
\hline Glomиs eburneum & 1 & 20 \\
\hline Glomus etunicatum & 4 & 80 \\
\hline Glomus fecundisporum & 1 & 20 \\
\hline Glomиs intraradices & 3 & 60 \\
\hline Glomиs macrocarpum & 4 & 80 \\
\hline Glomus margarita & 1 & 20 \\
\hline Glomus microcarpum & 1 & 20 \\
\hline Glomus mossea & 2 & 40 \\
\hline Glomus heterosporum & 2 & 40 \\
\hline Glomus sp. 1 & 3 & 60 \\
\hline Glomus sp. 2 & 1 & 20 \\
\hline Gigaspora decipiens & 3 & 60 \\
\hline Gigaspora sp. & 2 & 40 \\
\hline Pacispora boliviana & 2 & 40 \\
\hline Pacispora sp. & 2 & 40 \\
\hline Scutellospora castanea & 3 & 60 \\
\hline Scutellospora coralloidea & 3 & 60 \\
\hline Scutellospora fulgida & 2 & 40 \\
\hline Scutellospora heterogama & 1 & 20 \\
\hline Scutellospora sp. 1 & 1 & 20 \\
\hline Scutellospora sp. 2 & 1 & 20 \\
\hline
\end{tabular}

The lowest species richness was recorded at the control site and at the operated sites for two, three and ten years, with Margalef (S) indices of 1.73, 2.18, 1.97 and 2.7. The greatest wealth was recorded at the sites exploited for four and six years, with $S=4.67$ and 4.35). 


\section{Table 4}

Number of spores of AM fungal types in all study sites (expressed as Nb spores/100 $\mathrm{g}$ of soil)

\begin{tabular}{|c|c|c|c|c|c|c|}
\hline \multirow[t]{2}{*}{ Endomycorrhizal species } & \multicolumn{6}{|c|}{ Studied sites } \\
\hline & Site 0 & Site 2 & Site 3 & Site 4 & Site 6 & Site 10 \\
\hline A. colossica & 1 & 5 & & & & \\
\hline A. gedanensis & & & & & 3 & \\
\hline A. denticulata & & & 7 & 2 & 8 & \\
\hline A. laevis & & & 5 & 13 & & 3 \\
\hline A. foveata & & & & 3 & & \\
\hline A. mellea & & & & 1 & 3 & \\
\hline A. morrowiae & & & & 1 & 3 & \\
\hline A. scrobiculata & & & & & & 4 \\
\hline Acaulospora sp. 1 & & 16 & 11 & 10 & 2 & \\
\hline Acaulospora sp. 2 & 2 & & & 3 & & \\
\hline E. infrequens & 6 & & 7 & 19 & & \\
\hline G. aggregatum & & & & 15 & 9 & 2 \\
\hline G. clarum & 3 & & 6 & 1 & 4 & 3 \\
\hline G. corymbiform & & 2 & & & & \\
\hline G. deserticola & & 1 & & & & \\
\hline G. eburneum & & 1 & & & & \\
\hline G. etunicatum & & & 3 & 15 & 4 & 4 \\
\hline G. fecundisporum & & & & 4 & & \\
\hline G. intraradices & 5 & & & 6 & 5 & 4 \\
\hline G. macrocarpum & 1 & 6 & 3 & 7 & 5 & \\
\hline G. margarita & & & & & 3 & \\
\hline G. microcarpum & & & & & 3 & \\
\hline G. mossea & & & & & 13 & 3 \\
\hline G. heterosporum & & & & 5 & 2 & \\
\hline Glomus sp. 1 & & & 8 & & 6 & 2 \\
\hline Glomus sp. 2 & & & & & 2 & \\
\hline G. decipiens & & 5 & 8 & 3 & & \\
\hline Gigaspora sp. 2 & & 2 & & 5 & & \\
\hline P. boliviana & & & & 1 & 3 & \\
\hline Pacispora sp. & & & & 2 & 3 & \\
\hline S. castanea & & 1 & & 9 & & 2 \\
\hline S. coralloidea & & & & 7 & 5 & 4 \\
\hline S. fulgida & & & & 3 & 7 & \\
\hline S. heterogama & & & & & 6 & \\
\hline Scutellospora sp. 1 & & & & 2 & & \\
\hline Scutellospora sp. 2 & & & & 1 & & \\
\hline Total 36 & 18 & 43 & 58 & 138 & 99 & 27 \\
\hline
\end{tabular}


Table 5

Frequency and percentage distribution of AM fungal genera in the studied sites (six sites)

\begin{tabular}{llccccc}
\hline & Site 0 & Site 2 & Site 3 & Site 4 & Site 6 & Site 10 \\
\hline Acaulospora & 5.55 & 5.56 & 8.33 & 19.44 & 13.89 & 5.56 \\
Entrospora & 2.78 & 0 & 2.78 & 2.78 & 0 & 0 \\
Glomus & 8.33 & 11.11 & 13.89 & 19.44 & 30.56 & 16.67 \\
Gigaspora & 0 & 5.56 & 2.78 & 5.56 & & 0 \\
Pacispora & 0 & 0 & 0 & 5.56 & 5.56 & 5.56 \\
Scutellospora & 0 & 2.78 & 0 & 13.89 & 8.33 & 8.33 \\
\hline
\end{tabular}

Table 6

Diversity of endomycorrhizal species in the studied sites

\begin{tabular}{lcccc}
\hline Ecological zones & Number of species (S) & Total number (N) & $\begin{array}{c}\text { Margalef diversity } \\
\text { index }\end{array}$ & $\begin{array}{c}\text { Shannon } \\
\text { diversity index }\end{array}$ \\
\hline Site 0 & 6 & 18 & 1.73 & 1.59 \\
Site 2 & 9 & 39 & 2.18 & 1.77 \\
Site 3 & 9 & 58 & 1.97 & 2.12 \\
Site 4 & 24 & 138 & 4.67 & 2.82 \\
Site 6 & 21 & 99 & 4.35 & 2.61 \\
Site 10 & 10 & 27 & 2.73 & 2.44 \\
\hline
\end{tabular}

\section{Discussion}

The analysis of the rhizosphere soils of Saffron has shown the existence of a diverse and extensive community of mycorrhizal fungi. Indeed, in this study, up to 36 arbuscular fungal species belonging to six genera were isolated and identified. The highest AM fungal richness was recorded in site 4, occupied for four years by Saffron (24 species), followed by site 6 ( 21 species), six years of occupation by Saffron, and the lowest number of species was recorded in the sites exploited for two, three and ten years, 9 and 10 species, respectively.

The Glomus genus exists in six studied sites with a proportion of distribution that varies between $8.33 \%$ in site 0 (control) and $30.56 \%$ in site 6 . Various authors have associated the predominance of Glomus with its ability to produce, in a short time, more spores than other genera, case of Gigaspora and Scutellospora (Bever et al., 1996), and adapt to drought and soil salinity (Haas and Menge, 1990; Blaszkowski et al., 2002).

The diversity of AM fungi varies from one site to another, the site cultivated for four years by Saffron has recorded a value of Shannon's highest diversity index $\left(\mathrm{H}^{\prime}=2.82\right)$. Mohankumar and Mahadevan (1987) noted that environmental factors such as soil $\mathrm{pH}$, temperature, moisture, organic matter, and soil physical and chemical properties play an important role in the distribution of AM fungi. Other authors have noted that the diversity of AM fungal species decreases natural ecosystems to input-intensive farming systems (Hoseini and Rizvi, 2003), which is why plants can interact directly with other plants or with microorganisms by transmitting, receiving and responding to chemicals and other signals in their environment (Inderjit and Callaway, 2003). Saffron, medicinal plants, is among the plants that are known as strong allelopathic plants (Fuji et al., 1991). Some 
studies have reported the presence of flavonoid components in the saffron petal extract, and high concentrations of aqueous extracts of these petals reduced the growth of the length of radicles and cotton coleoptiles (Gossypium hirsutum L.) (Eskandari et al., 2007).

The significant decrease in spore counts and changes in AM fungi populations during the years of soil use by Saffron are probably due to the accumulation of allelopathic substances in the soil. This allelopathic effect of the plant on MA fungi has been reported by Pellissier and Trosset (1989). These authors noted that the presence of Molinia caerulea has a negative effect on endomycorrhizal populations. For its part, Rice (1984) reported that allo-chemical substances released into the environment have a relationship with their concentration and age.

Javaid et al. (1995) reported that the roots of allelopathic grasses are less colonized by endomycorrhizae than non-allelopathic Gramineae. Afzal et al. (2000) noted that aqueous extracts of leaves of Imperata cylindrica, allelopathic grass, reduce root colonization of Vigna radiata (L.) Wlczek and Phaseolus vulgaris L. plants by endomycorrhizae. Rashed-Mohassel et al. (2006a) reported that aqueous extract of corms and saffron leaves inhibit seed germination and root growth in Rapistrum rugosum and Rapistrum rugosum in vitro. Rashed-Mohassel et al. (2006b) reported that extracts of Saffron and corms have an inhibitory effect on redroot pigweed (Amaranthus retroflexus L.).

Many countries use controlled mycorrhization of plants, a biotechnological technique used in nurseries to obtain more robust plants that are also resistant to attack by pathogenic organisms and to water stress after transplantation (Branzanti et al., 1992; Rai, 2001; Guissou, 2001; Estrada-Luna et al., 2003).

\section{Conclusion}

This study showed the existence of AM fungi in the rhizosphere of Crocus sativus in the Taliouine region (Tinfat) and showed a significant decrease in the number of spores and changes in AM fungi populations during the years of land use by Saffron due to the accumulation in the soil of substances of allelopathic nature.

The soil of this region is rich in endomycorrhizae provides favorable conditions for the growth and development of Crocus sativus and increased tolerance to abiotic stress conditions (allelopathic substance, drought, salinity of water or soil) and microbiotic pathogenic organisms. The soil of Crocus sativus has a reserve of mycorrhizal fungi, can be isolated and used in the improvement and production of Saffron.

\section{Literature}

Aboudrare, A., AW-Hassan, A. and Lybbert, T-J. (2014): Importance socio-économique du Safran pour les ménages des zones de montagne de la région de Taliouine-Taznakht au Maroc. Rev. Mar. Sci. Agron. Vét. 2, 5-14.

Afzal, B., Bajwa, R. and Javaid, A. (2000): Allelopathy and VA mycorrhiza. VII: Cultivation of Vignaradiata and Phaseolus vulgaris under allelopathic stress of Imperatacylindrica. Pakistan J. Biological Sciences 3, 1926-1928.

Amir, H. and Renard, A. (2003): Etude microbiologique générale de quelques sols de forêts sclérophylles de Nouvelle-Calédonies: Statuts des mycorhizes à arbuscules. PCFS-UNC CP, 54, 22 p. 
Anonyme 1. (2004): Pauvreté, Développement Humain et Développement Social au Maroc. Données Cartographiques et Statistiques. Rapport. Haut Commissariat au Plan, Maroc.

Anonyme 2. (2015): Le Maroc vert, Ministère de l'Agriculture et de la pèche maritime: Contrats Programmes Pour Le Développement Des Filières De Production, édition. 17 p.

Anonyme 3. (2016): http://fungi.invam.wvu.edu/the-fungi/species-descriptions.html

Azizi Zohan, A. and Sepaskhah, A-R. (2002): The effect of leaching on soil improving and recultivation of saffron. The article abstract at Iran Seventh Congress of Agronomy, Karaj, 228 p. (In Persian).

Berch, S-M. and Koske, R-E. (1986): Glomuspansihalos, a new species in the Endogonaceae, Zygomycetes. Mycologia 78, 832-836.

Bever, J-D., Westover, K-M. and Antonovics, J. (1996): Incorporating the soil community into plant population dynamics: the utility of the feedback approach. J. Ecol. 85, 561-763.

Blaszkowski, J., Tadych, M. and Madej, T. (2002): Arbuscularmycorrhizal fungi (Glomales, Zygomycota) of the bledowska desert, Poland. Societastis Botanicorum Poloniae, 71, 71-85.

Bouchelkha, M. (2009): Etude Sociologique sur le Safran. Rapport de consultation. Maroc: Projet FAO/TCP/ MOR/3201.

Branzanti, B., Gianinazzi-Pearson, V. and Gianinazzi, S. (1992): Influence of phosphate fertilization on the growth and nutrient status of micropropagated apple infected with endomycorrhizal fungi during the weaning stage. Agronomie 12, 841-845.

Dalpé, Y. (1995): Systématique des endomycorhizes à arbuscules, de la mycopaléntologie à la biochimie. Orbis Press pp. 1-20.

Derkowska, E., Sas Paszt, L., Sumorok, B., Szwonek, E. and Gluszek, S. (2008): The influence of mycorrhization and organic mulches on mycorrhizal frequency in apple and strawberry roots. J. Fruit and Ornamental Plant Research 16, 227-242.

Dubois, A. (2010): Analyse de la filière du safran au Maroc: Quelle perspective pour la mise en place d'une indication géographique? Thèse de Master of Science, $N^{\circ} 107$. Montpellier: CIHEAM-IAMM.

Eskandari-Torbaghan, Abbasi, R. and Astarei Ali, R. (2007): Effect of Saffron (Crocus sativus L.) Petals on Germination and Primary Growth of Cotton (Gossypium hirsutum L.). Iran http://www.actahort.org/ books/739/739_10.htm

Estrada-Luna, A-A. and Davies, Jr-F-T. (2003): Arbuscular mycorrhizal fungi influence water relations, gas exchange, abscisic acid and growth of micropropagated chile ancho pepper (Capsicum annuum) plantlets during acclimatization and post-acclimatization. J. Plant Physiology 160, 1073-1083.

Ferrer, R-L. and Herrera, R-A. (1981): El genero Gigaspora Gerdemann et Trappe (Endogonaceae) en Cuba. Rev. Jardin Bot. Nacional Habana 1, 43-66.

Fuji, Y., Furukawa, M., Hayakawa, Y., Sugawara, K. and Shibuya, T. (1991): Survey of Japanese medicinal plants for the detection of allelopathic properties. Weed Res. 36, 36-42.

Garcin, G-D. and Carral, S. (2007): Le safran marocain entre tradition et marché. Etude de la filière du safran au Maroc, en particulier dans la région de Taliouine, province de Taroudant. Rapport de consultation. Maroc: Projet FAO/Association Migrations et Développement. http://www.mp-discussion.org/casablanca/doc/zaf.pdf

Gerdemann, J-W. and Nicholson, T-H. (1963): Spores for mycorrhizal endogone species extracted from soil by wet sieving and decanting. Trans. Br. Mycol. Soc., 46, 235-244.

Goussous, S-J. and Mohammad, M-J. (2009): Comparative effect of two arbuscular mycorrhizae and N and P fertilizers on growth and nutrient uptake of onions. International J. Agriculture and Biology 11, 463-467.

Guissou, T-G. (2001): La symbiose mycorhizienne à arbuscules chez des espèces ligneuses: diversité des Glomales, dépendance mycorhizienne, utilisation des phosphates naturels et tolérance a un stress hydrique. Thèse de doctorat soutenue a l'Université de Ouagadougou, $124 \mathrm{p}$.

Haas, J-H. and Menge, J-A. (1990): VA mycorrhizal fungi and soil characteristics in avocado (Persea Americana mill.) orchard soil. Plant and Soil, The Hague, v.127, n.2, pp. 207-212.

Hall, E-T. (1987): Hidden Differences: Doing Business with the Japanese. Garden City. NJ: Anchor Press/Doubleday, 172 p. Reviewed by Joel P. Bowman, Western Michigan University.

Harley, J-L. and Smith, S-E. (1983): Mycorrhizal Symbiosis. Academic Press, London, 483 p.

Hoseini, M. and Rizvi, S-J-H. (2003): Une étude préliminaire sur le rôle possible de l'allélopathie dans le safran (Crocus sativus L.). Troisième symposium national sur le safran, Iran. pp. 133-138. 
Inderjit, M. and Callaway, M. (2003): Experimental designs for study of allelopathy. Plant and Soil 256, 1-11.

Jadhav, P-S., Mulic, N-G. and Chavan, P-D. (1997): Effets allélopathiques d'Ipomoea carnea Fistulosa spp. sur la croissance du blé, du riz, du sorgho et du haricot rouge. Allelopathy J. 4, 345-348.

Jalali, A-K. (1962): Saffron in Kashmir. Prajna: Banaras Hindu University J. 7, 205-211.

Javaid, A., Bajwa, R., Tasneem, Z. and Nasim, G. (1995): Allelopathy and VA mycorrhiza. III: Vesicular arbuscular mycorrhizae (VAM) in allelopathic and non-allelopathic grasses. Science International (Lahore) 7, 545-547.

Khozaei, M., Kamgarhaghighi, A-A. and Sepaskhah, A. (2015): The effect of 10-year continuous saffron cultivation on physical and chemical properties of soil. Department of Water Engineering, College of Agriculture, Shiraz University, Iran Agricultural Research 34, 46-55.

Kobayashi, K. (2004): Facteurs affectant l'activité phytotoxique des substances alléliques dans le sol. Weed Bio. Manag. 4-17.

Kormanik, P-P. and McGraw, A-C. (1982): Quantification of vesicular-arbuscular mycorrhizae in plant roots. In: Methods and Principles of Mycchorizal Research. N.C. ed., APS Press, 37 p.

Lage, M. and Cantrell, C-L. (2009): Quantification des métabolites du safran (Crocus sativus L.) crocins, picrocrocine et safranal pour la détermination de la qualité des épices cultivées dans différentes conditions environnementales marocaines. Scientia-Horticulturae 121, 366-373.

Lone, R., Shuab, R., Sharma, V., Kumar, V., Mir, R. and Koul, K-K. (2015a): Effect of arbuscular mycorrhizal fungi on growth and development of potato (Solanum tuberosum) plant. Asian J. Crop Science 7, 233-243.

Lone, R,, Shuab, R., Wani, K-A., Ganaie, M-A., Tiwari, A-K. and Koul, K-K. (2015b): Mycorrhizal influence on metabolites, indigestible oligosaccharides, mineral nutrition and phytochemical constituents in onion (Allium cepa L.) plant. Scientia Horticulturae 193, 55-61.

Margalef, R. (1958): Information theory in ecology. Gen. Systems 3, 36-71.

Mohankumar, V. and Mahadevan (1987): Ecological distribution of VAM in tropical forest. In: Mycorrhiza Round Table Proceedings of the national workshop held at JNU, New Delhi, 13-15 March, pp. 238-256.

Morton, J-B. and Benny, G-L. (1990): Revised classification of arbuscular mycorrhizal fungi (Zygomycetes): A new order, Glomales, two new suborders, Glomineae and Gigasporineae, with an emendation of Glomaceae. Mycotaxon 37, 471-491.

Mukerji, K-G. and Kapoor, A. (1986): Occurrence and importance of vesicular-arbuscular mycorrhizal fungi in semiarid regions of India. For. Ecol. Mgmt., 16, 117-126.

Nicolson, T-H. and Johnston, C. (1979): Mycorrhiza in the gramineae. Glomus fasciculatum as the endophyte of pioner grasses in a maritime sand dune. Trans. Br. Mycol. Soc. 72, 261-268.

Onguene, N-A. (2000): Diversity and dynamics of mycorrhizal associations in tropical rain forests with different disturbance regimes in South Cameroon. Tropenbos Cameroon Series 3, 1-167.

Pellissier, F. and Trosset, L. (1989): Effect of phytotoxic solutions on the respiration of mycorrhizal and non mycorrhizal spruce roots (Piceaabies L Karst). Ann. Sci. For. 46 (suppl), 731s-733s.

Philips, J-M. and Hayman, D-S. (1970): Improved procedures for clearing roots and staining parasitic and VA mycorrhizal fungi for rapid assessement of infection. Trans. Br. Mycol. Soc. 55, 158-161.

Qarai, H. and Beigi, M. (1995): The study of changes in physicochemical and mineralogical properties of soil under saffron cultivation in Estahban. Report of Research, Department of Iran Scientific and Industrial Research, Shiraz, 37 p.

Rai, M-K. (2001): Current advances in mycorrhization in micropropagation. In Vitro Cell. Dev. Biol. Plant. 37, $158-167$.

Rashed-Mohassel Azizi, G. and Alimoradi, L. (2006a): Evaluation of allelopathic effects of saffron (Crocus sativa L.) extract on Rapistrum rugosum and Gypsophila pilosa germination. In: The 1st Iranian Weed Science Congeress, 25-26 January. pp. 257-261.

Rashed-Mohassel Azizi, G., Alimoradi, L. and Gherekhloo, J. (2006b): Evaluation of allelopathic effects of saffron (Crocus sativa L.) extract on redroot pigweed (Amaranthus retroflexus L.). In: The 1st Iranian Weed Science Congress, 25-26 January. pp. 285-288.

Rice, E-L. (1984): Allelopathy. Academic Press, New York, 353 p. 
Schenck, N-C. and Smith, G-S. (1982): Additional new and unreported species of mycorrhizal fungi (Endogonaceae) from Florida. Mycologia 77, 566-574. Reproduced with permission from Mycologia. (C)The Mycological Society of America.

Schenck, N-C. and Perez, Y. (1987): Manual for Identification of VAM Fungi. 1453 Fifield Hall Univ, Florida, U.S.A.

Shannon, C-E. and Weaver, W. (1949): The Mathematical Theory of Communication. The University of Illinois Press, Urbana, IL: 117 p.

Sharif, M. and Moawad, A-M. (2006): Arbuscular mycorrhizal incidence and infectivity of crops in North West Frontier Province of Pakistan. World J. Agricultural Sciences 2, 123-132.

Smith, S-E and Read, D-J. (1997): Mycorrhizal Symbiosis. 2nd ed. Academic Press, San Diego, California, USA, 800 p.

Strullu, D-G. (1991): Les mycorhizes des arbres et des plantes cultivées. Lavoisier Paris. $3^{\text {éme }}$ edit 249 p.

Sylvia, D-M. and Williams, S-E. (1992): Vesicular-arbuscular mycorrhizae and environmental stresses. In: G. J. Bothlenfalvay and R. G. Linderman (eds): Mycorrhizae in Sustainable Agriculture. American Society of Agronomy, Inc. Madison, Wisconsin, USA, pp. 101-123.

Walker, C. and Mize, C-W. (1982): Population of endogonaceous fungi at two locations in central Iowa. Can. J. Bot. $60,2518-2529$. 